\title{
STRATEGI PENGHIMPUNAN DANA INFAQ TELAAH EFEKTIVITAS APLIKASI DIGITAL PADA AT-TAQWA CENTRE KOTA CIREBON
}

\author{
M. Mabruri Faozi dan Awalia Jehan S. \\ Institut Agama Islam Negeri Syekh Nurjati Cirebon \\ Email:mabruri2020@gmail.com danawli474@gmail.com
}

\begin{abstract}
At-Taqwa Center in Cirebon City is one of the mosques that uses the QR Code feature as a strategy for collecting infaq funds. With a large number of worshipers and coming from various regions, this is an opportunity for the Cirebon City At-Taqwa Center to facilitate non-cash donations and can increase the amount of infaq funds raised.This study aims to determine the implementation of the QR Code feature, the effectiveness of the QR Code feature as one of the infaq fund raising strategies, and the solution of the inhibiting factors of the $Q R$ Code feature at the At-Taqwa Center in Cirebon. This research uses a qualitative research method using descriptive. The results of the research that the infaq fund collection strategy through the $Q R$ Code feature was not effective enough in raising infaq funds, seeing an unstable increase and decrease in income each month.
\end{abstract}

Keywords: Infaq, Digital Application, and QR Code.

\begin{abstract}
Abstrak
At-Taqwa Centre Kota Cirebon merupakan salah satu masjid yang menggunakan fitur QR Code sebagai salah satu strategi dalam penghimpunan dana infaqnya. Dengan jamaahnya yang cukup banyak dan datang dari berbagai wilayah, ini merupakan suatu peluang bagi AtTaqwa Centre Kota Cirebon untuk memudahkan jamaah berinfaq secara non tunai dan dapat menambah jumlah perolehan dana infaq. Penelitian ini bertujuan untuk mengetahui implementasi fitur QR Code, efektivitas fitur $Q R$ Code sebagai salah satu strategi penghimpunan dana infaq, dan solusi dari faktor penghambat fitur QR Code pada At-Taqwa Centre Kota Cirebon. Penelitian ini menggunakan metode penelitian kualitatif dengan pendekatan deskriptif. Hasil penelitian menyatakan bahwa strategi penghimpunan dana infaq melalui fitur QR Code belum cukup efektif dalam menghimpun dana infaq melihat peningkatan dan penurunan pendapatan setiap bulannya yang tidak stabil.
\end{abstract}

Kata Kunci: Infaq, Aplikasi Digital, dan QR Code. 


\section{PENDAHULUAN}

Di era globalisasi ini, perkembangan teknologi informasi dan komunikasi semakin maju diberbagai belahan dunia termasuk negara Indonesia. Bahkan pengguna smartphone di Indonesia mencapai 92 juta unit dan proyeksi pengguna internet di Indonesia tahun 2020 juga mencapai 119,4 juta pengguna (Katadata, 2019). Perkembangan teknologi ini membawa banyak perubahan terhadap berbagai sektor kehidupan manusia, salah satunya ialah dalam hal transaksi keuangan. Dahulu, masyarakat Indonesia terbiasa menggunakan uangnya sebagai alat pembayaran tunai saat membeli suatu barang. Kini hadir inovasi baru yang memudahkan masyarakat dalam melakukan transaksi yang lebih efisien yakni pembayaran non- tunai melalui e-money.

Berdasarkan data dari Bank Indonesia, jumlah transaksi uang elektronik selama tahun 2019 makin meningkat disetiap bulannya. E-money menjadi salah satu alternatif yang amat potensial dalam mendorong peningkatan inklusi keuangan. Saat ini hampir seluruh perbankan besar di Indonesia memiliki layanan e-money yang kemudian disusul oleh pelaku bisnis startup dibidang fintech seperti Tokopedia dengan OVO atau Gojek dengan Gopay.

Sejauh ini sudah ada 26 perusahaan yang telah terdaftar resmi menjadi pemegang lisensi e-money BI (Eka, 2019). Terdaftarnya banyak perusahaan yang menjadi pemegang lisensi e-money menandakan bahwa bisnis digital payment di Indonesia semakin berkembang. Setelah sistem pembayaran melalui e-money, kini telah hadir inovasi baru yang masih menjadi bagian dari $e$ money yakni sistem pembayaran melalui teknologi $Q R$ Code atau $Q R$ Payment. $Q R$ Payment adalah sistem embayaran elektronik dengan memindai $Q R$ Code. QR Code sangat praktis ketika digunakan karena penyampaian informasi harga atau tagihan serta responnya sangat cepat. Tidak hanya untuk memenuhi kebutuhan sehari-hari saja, QR Payment juga hadir untuk menjangkau lembaga-lembaga amal yang bekerja sama dengan aplikasi penerbit uang elektronik dan merchant tertentu agar memudahkan masyarakat Indonesia yang ingin berbagi sesama kepada orang yang membutuhkan (sedekah/infaq) atau hanya sekedar membayar kewajiban seperti zakat.

Pada tahun 2018, Go-Jek meluncurkan fitur terbaru yang bekerjasama dengan Baznas yakni sedekah online menggunakan Go-Pay dengan tagline "Scan untuk bersedekah: Bantu mereka yang tidak mampu dengan bersedekah ke BAZNAS menggunakan saldo GO-PAY kamu!". Selain itu, aplikasi mobile financial services dari Telkomsel, TCash juga merilis layanan serupa sejak tahun lalu. TCash meletakkan QR Code tersebut di kotak amal di lebih dari 100 masjid di Bandung, Jakarta, Purwokerto, Lombok Tengah (Setyowati, 2019).

Kemudian, lembaga filantropi Islam seperti Dompet Dhuafa juga menjalin kerjasama dengan OVO guna memberikan akses digital kepada masyarakat dalam menunaikan Zakat, Infaq dan Shadaqah melalui aplikasi digital. Kini banyak bankbank besar dan perusahaan startup yang menyediakan fitur zakat, infaq dan sedekah berbasis online untuk memudahkan pelanggannya berbuat baik terhadap sesama atau transaksi untuk ibadah. Ini juga merupakan suatu bentuk kepedulian atau kepekaan mereka terhadap pengembangan dana sosial untuk turut membantu kesejahteraan sesama manusia dengan teknologi yang ada. Dengan adanya kolaborasi antara fintech dan lembaga amal sebagai penyalur infaq/sedekah, ini merupakan inovasi baru serta peluang yang sangat bagus dalam usaha meningkatkan perolehan dana infaq/sedekah di Indonesia.

Salah satu masjid yang memiliki fitur lengkap untuk berinfaq terutama melalui aplikasi digital berupa $Q R$ Code di Kota Cirebon ialah Masjid Raya At-Taqwa. Dengan jamaahnya yang cukup banyak dan datang dari berbagai wilayah, ini merupakan suatu peluang bagi At-Taqwa Centre Kota Cirebon dalam menghimpun dana infaq yang 
lebih banyak. Fitur infaq secara online ini memudahkan jamaah untuk berinfaq secara non tunai dan dapat menambah jumlah perolehan sedekah bagi Masjid Raya AtTaqwa. Sistem $Q R$ Code menjadikan infaq lebih dekat dengan masyarakat dan generasi millenial, karena sistem pembayaran $Q R$ Code yang tersedia kapan saja dan dimana saja. Selain itu, kinerja At-Taqwa Centre Kota Cirebon khususnya dana infaq terlihat lebih profesional dan dengan itu kepercayaan masyarakat pun akan meningkat.

Infaq berbasis aplikasi digital bukan lagi menjadi suatu harapan dalam jangka panjang, tetapi juga jangka pendek. Fitur $Q R$ Code mampu meningkatkan daya penghimpunan dana infaq di At-Taqwa Centre Kota Cirebon. Implementasi fitur online sedekah QR Code seharusnya memiliki dampak yang cukup signifikan terhadap pengumpulan dana sedekah yang ada. Karena melihat peluang berdasarkan data pengguna smartphone dan internet diatas serta tren cashless yang ada saat ini, yang juga sejalan dengan upaya pemerintah dan Bank Indonesia untuk mendorong transaksi non tunai yang lebih dikenal dengan nama Gerakan Nasional Non Tunai (GNNT). Sehingga potensi dana infaq/sedekah Indonesia terealisasi.

Berdasarkan uraian diatas, peneliti memiliki ketertarikan untuk melakukan penelitian terkait implementasi fitur QR Code di At-Taqwa Centre Kota Cirebon, efektivitas fitur QR Code sebagai salah satu strategi penghimpunan dana infaq pada

At-Taqwa Centre Kota Cirebon dan solusi terhadap faktor penghambat yang ada dalam fitur QR Code pada At-Taqwa Centre Kota Cirebon.

\section{LITERATURE REVIEW}

Setelah penulis melakukan berbagai penelusuran dan pencarian terkait judul penelitian ini, maka penulis menemukan beberapa penelitian terdahulu yang berkaitan dengan judul penelitian, yaitu: pertama jurnal yang berjudul "Analisis Strategi
Fundraising Terhadap Peningkatan Pengelolaan ZIS Pada Lembaga Amil Zakat Kabupaten Ponorogo." (Atik Abidah, Jurnal Ilmiah, 2016). Dalam jurnal ini, permasalahan yang dibahas adalah strategi fundraising (penghimpunan dana zakat) dan dampak dari strategi tersebut pada peningkatan pengelolaan dana zakat pada Lembaga Amil Zakat di Kabupaten Ponorogo. Selain itu, metode yang digunakan dalam jurnal ini menggunakan pendekatan kualitatif. Hasil penelitian ini menyimpulkan bahwa strategi fundraising dalam peningkatan pengelolaan ZIS pada berbagai LAZ di Kabupaten Ponorogo, menunjukkan LAZ yang bertaraf nasional mampu mengumpulkan dana yang lebih banyak dibandingkan dengan LAZ lokal, bahkan beberapa LAZ lokal mengalami penurunan dalam menerima ZIS dalam beberapa tahun terakhir. Hal ini disebabkan 1) Brand image lembaga LAZ yang bagus mempengaruhi pemahaman masayarakat untuk terlibat dalam pengumpulan ZIS kepada lembaga tersebut. 2) Amil yang profesional dengan sistem manajemen yang bagus berpengaruh terhadap strategi fundraising, keuangan, maupun kinerja sebuah organisasi. Sebagian besar LAZ lokal hanya mengandalkan sistem tradisional dengan SDM yang lemah. Hal yang menjadi kesamaan dari skripsi ini dengan skripsi peneliti adalah kesamaan metode kualitatif dan menganalisis strategi fundraising lembaga ZIS. Adapun yang menjadi pembeda adalah skripsi ini menganalisis strategi fundraising secara umum yang digunakan oleh LAZ sedangkan peneliti hanya menganalisis salah satu strategi yang digunakan oleh At-Taqwa Center yakni strategi melalui fitur $Q R$ Code. Kemudian peneliti hanya fokus kepada strategi infaq.

$$
\text { Kedua, "Analisis Efektivitas }
$$

Penerapan Strategi Pengumpulan Dana Zakat, Infak dan Sedekah Bagi Peningkatan Jumlah Muzakki di Baznas Kota Semarang (Tahun 2013-2015)." (Noviana, Skripsi, 2016). Dalam skripsi ini, permasalahan yang dibahas adalah efektifitas strategi 
pengumpulan pengumpulan dana zakat, infak, dan sedekah bagi peningkatan jumlah muzakki di Badan Amil Zakat Nasional Kota Semarang. Selain itu, metode yang digunakan dalam jurnal ini menggunakan pendekatan kualitatif. Metode analisis data yang digunakan adalah metode analisis deskriptif.

Hasil dari penelitian ini adalah penerapan strategi pengumpulan dana zakat, infak dan sedekah di Badan Amil Zakat Nasional Kota Semarang dilakukan dengan melakukan penghimpunan dana dan penghimpunan donatur melalui pembentukan koordinator setiap kelurahan dalam menghimpun dana dan donatur, menghimpun simpatisan dan pendukung melalui publikasi secara transparan juga komunikasi dengan baik dengan masyarakat sehingga orang tersebut tertarik untuk menjadi agen lembaga, membangun citra lembaga melalui transparansi administrasi dan pelaporan, dan memuaskan donatur melalui program-program yang dapat memuaskan donatur. Sedangkan metode yang digunakan secara langsung melalui door to door, melibatkan pemberi ZIS dalam program lembaga, bimbingan rohani, melakukan dakwah di tempat muzakki dan dilakukan secara tidak langsung melalui dakwah bulletin keluarga Sakinah, proposal kerjasama, pamflet, reklame, brosur, dakwah berupa pengajian, khutbah jum "eat dan acara keagamaan lain. Kedua, strategi pengumpulan dana zakat, infak, dan sedekah efektif bagi peningkatan jumlah muzakki di Badan Amil Zakat Nasional Kota Semarang dengan indikasi meningkatkan input atau pemasukan ZIS dan meningkatnya jumlah pemberi zakat setiap tahunnya dan kualitas penerima zakat, bahkan orang yang dulunya sebagai mustahiq banyak yang berubah menjadi muzakki sehingga meningkatkan dana yang terkumpul.

Hal yang menjadi kesamaan dari skripsi ini dengan skripsi peneliti adalah kesamaan metode kualitatif dan mencari efektivitas strategi penghimpunan dana lembaga ZIS. Adapun yang menjadi pembeda adalah skripsi ini menganalisis efektivitas strategi penghimpunan dana secara umum yang digunakan oleh Baznas dan dampaknya pada peningkatan jumlah muzakki sedangkan peneliti hanya menganalisis efektivitas salah satu strategi yang digunakan oleh At-Taqwa Center yakni strategi melalui fitur $Q R$ Code dan dampaknya terhadap perolehan dana. Kemudian peneliti hanya fokus kepada strategi infaq.

Ketiga, jurnal yang berjudul "Efektifitas Penyaluran Zakat, Infak, Sedekah Melalui Aplikasi Online" (Siti Masruroh, Jurnal Ilmiah, 2019). Dalam jurnal ini, permasalahan yang dibahas adalah efektifitas penyaluran zakat, infak dan sedekah melalui aplikasi online. Supaya penyalurannya zakat, infaq dan sedekah bisa terkontrol dengan baik dan pemberi zakat bisa melihat langsung kemana dana zakat itu disalurkan. Selain itu, metode yang digunakan dalam jurnal ini menggunakan pendekatan kualitatif. Hasil dari penelitian ini adalah sistem aplikasi zakat, infak dan sedekah sangat diperlukan sebagai saran penerimaan dan penyaluran dana umat dengan tepat sasaran. Diharapkan dengan sistem aplikasi online ini akan terkumpul dana yang lebih terkoordinasi dengan sistematis kepada masyarakat bahwa zakat merupakan hal yang wajib dibayarkan. Sistem aplikasi zakat, infak, dan sedekah yang dibuat telah terkomputerisasi dan menjadi solusi alternatif untuk membantu dalam proses manajemen penyaluran zakat, infak dan sedekah. Dengan sistem ini pengguna mengecek dan mencetak informasi penerimaan dan penyaluran donasi perhari, perminggu atau perbulan dari hasil laporannya. Hal yang menjadi kesamaan dari skripsi ini dengan skripsi peneliti adalah kesamaan metode kualitatif dan efektivitas penyaluran dana ZIS yang berfokus pada aplikasi online. Adapun yang menjadi pembeda adalah fokus pada skripsi ini adalah zakat. Sedangkan peneliti adalah infaq. Selain 
itu, aplikasi online yang dibahas pun umum sedangkan peneliti fokus pada $Q R$ Code.

Keempat, Penelitian dengan judul

"Dampak Penerapan Strategi Fundrising

Terhadap Peningkatan Pengelolaan Dana Zakat (Studi Pada Dompet Dhuafa Cabang Yogyakarta" (Muhammad Ronald Reagen, Skripsi, 2018). Dalam jurnal ini, permasalahan yang dibahas adalah strategi fundraising dan dampaknya terhadap peningkatan pengelolaan dana zakat di Dompet Dhuafa cabang Yogyakarta. Selain itu, metode yang digunakan dalam jurnal ini menggunakan pendekatan kualitatif. Metode analisis yang digunakan adalah dengan menggunakan pendekatan kualitatif deskriptif.

Hasil dari penelitian ini adalah Shariat Islam mengandungi sistem pengurusan ekonomi dan keuangan yang sangat komprehensif dan menyediakan instrumen yang secukupnya bagi mengatasi masalah kemiskinan dan kefakiran. Isu yang utama adalah pengutipan dan pengagihan. Di antara instrumen-instrumen keuangan Islam yang mampu digembelingkan dengan skala besar ialah sedekah. Dana sedekah mempunyai potensi yang sangat tinggi untuk dibangunkan, terutamanya di dalam sistem ekonomi dan keuangan yang berasaskan teknologi maklumat dan komunikasi pada hari ini. Sistem kuangan Islam Malaysia yang telah mencapai tahap kemajuan yang agak tinggi mampu menyediakan infrastruktur yang lengkap bagi penubuhan.

Hal yang menjadi kesamaan dari skripsi ini dengan skripsi peneliti adalah kesamaan metode kualitatif dan dampak penerapan strategi fundrising terhadap peningkatan pengelolaan dana. Adapun yang menjadi pembeda adalah fokus pada skripsi ini adalah zakat. Sedangkan peneliti adalah infaq. Selain itu, peneliti fokus pada salah satu strategi yakni aplikasi digital QR Code. Sedangkan skripsi ini strategi secara umum.

Kelima,Penelitian dengan judul "Efektivitas Strategi Digital Marketing Pada Penghimpunan Dana Zakat, Infaq, dan Shodaqoh (ZIS) dengan Pendekatan Direct
Rating Method (DRM). (Studi Kasus NU CARE LAZISNU Jakarta Pusat)" (Dzurriyatun Nafiah, Skripsi, 2018). Dalam jurnal ini, permasalahan yang dibahas adalah efektivitas strategi digital marketing pada penghimpunan dana zakat, infaq, dan shodaqoh (zis) dengan pendekatan direct rating method (DRM). Selain itu, jenis penelitian yang digunakan adalah penelitian deskriptif kuantitatif dengan cara mengumpulkan data-data yang diperlukan. Kemudian dianalisa dengan metode DRM (Direct Rating Method) dan diinterpretasikan.Hasil dari penelitian ini adalah strategi digital marketing melalui facebook, twitter dan instagram dengan pendekatan DRM dikategorikan efektif. Dengan melihat rentang skala bobot yang diperoleh dengan hasil: attention 3,18; read thoroughness 3,06; cognitive 2,97; affective 3,09; dan behavior 3,22. Nilai total skor DRM sebesar 62,09 masuk dalam kategori iklan baik berdasarkan pada table direct rating.

Hal yang menjadi kesamaan dari skripsi ini dengan skripsi peneliti adalah kesamaan membahas efektivitas strategi pada penghimpunan dana zakat, infaq, dan shodaqoh dan dalam skripsi peneliti juga membahas strategi penghimpunan dana melalui sosial media. Adapun yang menjadi pembeda adalah jenis penelitian dan teknik analisis skripsi ini menggunakan penelitian kuantitatif dan dianalisis menggunakan metode DRM (Direct Rating Method).Hasil dari penelitian di atas secara umum berkaitan erat dengan penelitian yang akan peneliti lakukan, akan tetapi secara khusus penelitian tersebut sedikit berbeda dengan permasalahan yang akan diteliti dengan penelitian ini. Belum ada penelitian yang khusus membahas mengenai efektivitas infaq melalui aplikasi digital berupa fitur $Q R$ Code. Dengan demikian peneliti memandang sebagaimana yang telah dijelaskan dalam latar belakang, bahwa dalam penelitian mengenai "Strategi Penghimpunan Dana Infaq; Telaah Efektivitas Aplikasi Digital p ada At-Taqwa Centre Kota Cirebon” layak untuk dilakukan. 


\section{METODOLOGI PENELITIAN}

Penelitian ini adalah penelitian lapangan (field research) dengan metode penelitian kualitatif. Sumber data primer dalam penelitian ini adalah data-data yang penulis peroleh langsung baik melalui wawancara, observasi maupun dokumentasi di At-Taqwa Centre Kota Cirebon. Sumber data sekunder dalam penelitian ini adalah berbentuk buku, internet, karya tulis, dan tulisan maupun artikel yang berhubungan dengan objek penelitian. Untuk metode pengumpulan data yang digunakan dalam penelitian ini adalah wawancara, observasi, dokumentasi dan analisis data melalui metode deskripsi.

\section{PEMBAHASAN DAN DISKUSI \\ Strategi Penghimpunan Dana}

Penghimpunan dana (fundraising) adalah suatu kegiatan yang dilakukan untuk menggalang dana dan daya lainnya dari masyarakat yang akan digunakan untuk membiayai program dan kegiatan operasional lembaga sehingga mencapai tujuan (Buhari, 2018). Penghimpunan dana (fundraising) juga merupakan kegiatan mempengaruhi masyarakat atau calon donatur agar mau melakukan amal kebajikan dalam bentuk menyerahkan sebagian hartanya. Untuk mendapatkan hasil yang maksimal fundraising membutuhkan strategi dan pendekatan yang tepat (Ghofur, 2018). Strategi merupakan rencana skala besar yang berorientasi jangka panjang untuk berinteraksi dengan lingkungan yang kompetitif untuk mencapai tujuan perusahaan (John A. Pearce II, 2013). Strategi memberikan pengarahan terpadu bagi suatu lembaga dan memberikan pedoman pemanfaatan sumber daya yang digunakan untuk mencapai tujuan.

Sedangkan Dengan adanya strategi fundraising, lembaga dapat berjalan secara efektif dan mandiri dalam menjalankan kegiatannya secara berkelanjutan.

\section{Infaq}

Infaq berasal dari kata anfaqa yang artinya mengeluarkan, membelanjakan (harta/uang).
Dalam Kitab At Tä'rifat, Syaikh Al-Jurjani mendefinisikan infaq adalah penggunaan harta untuk suatu hajat (kebutuhan). Sehingga menurut definisi ini infaq berkaitan dengan amal materi (harta/mal). Infak adalah segala macam bentuk pengeluaran (pembelanjaan) baik untuk kepentingan pribadi, keluarga ataupun yang lain (Arifin, 2011).

Istilah yang dipakai dalam Al-Qur'an berkenaan dengan infaq meliputi kata: zakat, shadaqah, hadyu, jizyah, hibah dan wakaf. Jadi semua bentuk perbelanjaan atau pemberian harta kepada hal yang disyariatkan agama dapat dikatakan infaq, baik itu berupa kewajiban seperti zakat atau yang berupa sunnah seperti wakaf atau shadaqah (Mardani dalam Uyun, 2015) Hukum infaq adalah wajib, jika bentuknya pemberian nafkah (suami kepada istri dan keluarga), nazar, kafarat dan zakat. Sedangkan hukum infaq adalah sunnah, jika pemberian harta kepada fakir miskin, anak yatim, pembangunan masjid/sekolah/pondok, sumbangan untuk korban bencana dan lainnya. Infaq dikeluarkan oleh setiap orang yang beriman, baik yang berpenghasilan tinggi maupun rendah, baik disaat berkecukupan harta maupun kekurangan. Infaq tidak mengenal nishab atau batasan jumlah harta dan tidak harus diberikan kepada mustahiq tertentu (Arifin, 2011).

\section{Efektivitas}

Menurut Kamus Besar Bahasa Indonesia (KBBI) efektif memiliki beberapa arti, antara lain: (1) ada efeknya (akibatnya, pengaruhnya, kesannya), (2) dapat membawa hasil, berhasil guna (tentang usaha, tindakan), (3) mulai berlaku (tentang undang-undang, peraturan).

Sedangkan keefektivan ialah (1) keadaan berpengaruh, hal berkesan, (2) kemanjuran atau kemujaraban (tentang obat). (3) keberhasilan (tentang usaha, tindakan) atau (4) hal mulai berlakunya (tentang undang-undang, peraturan). Dalam pengertian yang lain, efektivitas berarti membawa hasil. Artinya sesuatu dapat 
dikatakan efektif apabila berhasil dan dapat mencapai tujuan sebagaimana yang telah dirumuskan atau direncanakan sebelum melakukan hal tersebut. Efektivitas merupakan kemampuan untuk memilih tujuan yang tepat atau peralatan yang tepat untuk pencapaian tujuan yang telah ditetapkan (Handoko, 2015). Efektif dalam lembaga infaq berarti bagaimana amil mengelola dana dengan tepat dan menyalurkannya sesuai sasaran. Efektif dalam penghimpunan dana berarti bagaimana strategi yang tepat agar dana yang berhasil dihimpun cukup banyak.

\section{Tolak Ukur Efektivitas}

Adapun yang menjadi tolak ukur suatu program atau rencana dikatakan efektif adalah sebagai berikut (Handoko, 2015), antara lain; a) Kegunaan, yakni agar berguna bagi manajemen dalam pelaksanaan fungsifungsinya yang lain, suatu rencana harus fleksibel, stabil, berkesinambungan dan sederhana. b) Ketepatan dan objektifitas, maksudnya semua rencana harus dievaluasi untuk mengetahui apakah jelas, ringkas, nyata dan akurat. c) Ruang lingkup, yakni perlu memperhatikan prinsip-prinsip kelengkapan, kepaduan dan konsistensi. d) Efektivitas biaya, dalam hal ini Efektivitas biaya menyangkut waktu, usaha dan aliran emosional. e) Akuntabilitas, terdapat dua aspek akuntabilitas; pertama tanggung jawab atas pelaksanaan, kedua tanggung jawab atas implementasinya. f) Ketepatan waktu, yakni suatu perencanaan, perubahan-perubahan yang terjadi sangat cepat akan dapat menyebabkan rencana tidak tepat atau sesuai untuk berbagai perbedaan waktu.

\section{Aplikasi Digital}

Banyak perusahaan telah beradaptasi dengan kecanggihan teknologi saat ini. Salah satunya dengan memulai perjalanan transformasi digital untuk mencoba cara digital baru dalam berbisnis. Ini berarti, data dimanfaatkan secara lebih cerdas untuk menghadirkan tingkat efisiensi, efektivitas, kelincahan (agility), dan produktivitas yang belum pernah dicapai sebelumnya (Syahbana, 2020). Adanya aplikasi digital yang sebelumnya hanya digunakan sebagai alat bantu komunikasi, kini telah berkembang menjadi sebuah layanan yang dibuat sesuai permintaan pasar. Seperti aplikasi Go-Jek atau Grab yang merupakan aplikasi penyedia transportasi secara online. Kemudian perusahaan e-commerce pun menyediakan aplikasi digital tertentu seperti Shopee, Tokopedia dan Bukalapak. Tidak hanya itu, lembaga filantropi Islam seperti dompet dhuafa pun meluncurkan platform layanan digital bernama Mumu untuk mempermudah masyarakat dalam melakukan donasi. Melalui Mumu masyarakat bisa berdonasi zakat, wakaf, dan donasi sosial lainnya. Sebuah perusahaan atau organisasi pengelola zakat, infak dan sedekah akan memiliki kesempatan yang sama untuk mengakses dan diakses oleh masyarakat dengan adanya aplikasi digital tersebut.

\section{Aplikasi QR Code}

Kode QR adalah sebuah kode matriks atau dua dimensi bar code yang dibuat oleh perusahaan Jepang Denso Wave pada tahun 1994 (Malik, 2010). Tujuan dari QR Code ini adalah untuk menyampaikan informasi secara cepat dan juga mendapat tanggapan secara cepat. Kode QR (Quick Respons) merupakan bentuk evaluasi dari code yang biasanya dilihat pada sebuah produk. Kode QR berbentuk jajaran persegi berwarna hitam berbentuk seperti code tetapi dengan tampilan lebih ringkas. $Q R$ Code menawarkan banyak manfaat, seperti membatasi jumlah kertas yang digunakan dalam bertransaksi. QR Code memiliki kapabilitas koreksi kesalahan untuk mengembalikan data jika kode mengalami kerusakan atau kotor (Arianti, 2019). Beberapa manfaat yang terdapat pada sistem barcode antara lain: akurasi. Kemudahan pemakaian. keseragaman pengumpulan data, feedback yang tepat waktu, keamanan, meningkatkan produktivitas, dan meningkatkan profit (Malik, 2010). Selain itu, QR Code memiliki kapasitas data untuk $Q R$ Code dibandingkan 
matriks kode yang lain dapat dikatakan cukup besar, yatitu dapat menampung 7.089 data numeric, 4.296 data alfanumerik, 2.953 data biner, atau 1.817 karakter kanji dengan dukungan kecepatan pengkodean dan ukuran cetak yang kecil (Malik, 2010).

Perkembangan jaman digital telah membuat $Q R$ Code semakin banyak dimanfaatkan di banyak industri dan kehidupan. Cara membuat kode batang QRCode yang mudah dan dapat diperoleh dengan gratis membuat penggunaannya semakin diminati oleh berbagai kalangan. Terlebih mayoritas masyarakat di Indonesia memiliki smartphone atau ponsel pintar. Setiap ponsel pintar atau komputer yang memiliki fitur kamera sudah dapat digunakan sebagai mesin pembaca $Q R$ Code (Damara, 2017).

\section{PEMBAHASAN DAN DISKUSI \\ Implementasi Infaq Melalui Fitur $Q R$ Code Pada At-Taqwa Centre Kota Cirebon}

Dalam menyesuaikan diri terhadap kemajuan teknologi, $Q R$ Code menjadi salah satu strategi yang dipilih oleh At-Taqwa Centre dalam menghimpun dana infaq jariyah dari jamaah. Dalam ruang lingkup At-Taqwa sendiri, banyak jamaah yang terlihat menggunakan smartphonenya. Melihat peluang serta kebutuhan jamaah yang menggunakan layanan e-payment, AtTaqwa Centre pun menghadirkan sistem pembayaran melalui aplikasi digital berupa fitur $Q R$ Code. Selain itu, terdapat dukungan dari beberapa pihak seperti perusahaan penyedia jasa fitur $Q R$ Code, bank syariah, dan lembaga At-Taqwa Centre itu sendiri, yang pada akhirnya membuat At-Taqwa Centre menyediakan pembayaran infaq melalui fitur ini (Malik, 2020). Peneliti menemukan bahwa fitur $Q R$ Code yang ada di At-Taqwa Centre ada dua macam kepemilikan. Pertama, $Q R$ Code yang dimiliki dan dikelola oleh lembaga AtTaqwa Centre itu sendiri. Kedua, QR Code yang dimiliki dan dikelola oleh Laziswa AtTaqwa (salah satu Unit Kegiatan Masjid
(UKM) At-TaqwaCentre). Dua fitur yang sama ini memiliki beberapa perbedaan yaitu perolehan dana $Q R$ Code yang dimiliki AtTaqwa Center disalurkan hanya untuk operasional masjid dan dana yang dihimpun hanya infaq jariyah saja. Sedangkan perolehan dana $Q R$ Code yang dimiliki Laziswa, penyaluran dan penghimpunan dananya lebih beragam. Selain infaq, $Q R$ Code tersebut dapat digunakan untuk zakat dan sedekah. Cakupannya pun lebih luas yakni untuk dana sosial, pendidikan dan sebagainya.

Dimulai sejak bulan Mei 2018, TCash atau sekarang berubah nama menjadi LinkAja merupakan aplikasi $e$-wallet pertama yang bekerja sama dengan At-Taqwa Center dalam penerimaan infaq melalui fitur $Q R$ Code. Setelah itu ada aplikasi penyedia jasa pembayaran non-tunai lainnya seperti OVO, GOPAY dan DANA yang menyusul. Selain fitur $Q R$ Code melalui aplikasi $e$-wallet yang telah disebutkan, pada bulan April 2019 AtTaqwa Centre juga bekerja sama dengan Bank Syariah Mandiri dalam penyediaan fitur infaq melalui $Q R$ Code yang tersedia pada layanan internet banking. Sehingga dana yang masuk akan otomatis masuk ke rekening Bank Syariah Mandiri yang dimiliki At-Taqwa Centre. Sedangkan dana dari aplikasi $e$-wallet akan masuk ke rekening Bank BRI Syariah.

Sistem infaq melalui fitur $Q R$ Code yang telah dilaksanakan oleh At- Taqwa Centre tidak langsung bisa diterima secara menyeluruh dalam waktu singkat. At-Taqwa Centre membutuhkan waktu dan media sosialisasi untuk lebih mengenalkan kepada masyarakat diarea tersebut bahwa At-Taqwa Center memiliki fitur $Q R$ Code, tidak hanya kotak infaq. Penggunaan media sosial, banner $Q R$ Code yang cukup besar, dan penyimpanan $Q R$ Code ditempat yang strategis merupakan cara yang digunakan oleh At-Taqwa Center untuk mempromosikan fitur $Q R$ Code kepada khalayak ramai. Penggunaan media sosial ini diantaranya melalui akun facebook dan instagram At-Taqwa Center. Untuk media 
sosial biasanya At-Taqwa Center mempromosikan infaq dengan cara memposting foto dari $Q R$ Code dan mengajak pengikut akun untuk berinfaq. Sedangkan banner $Q R$ Code yang cukup besar disimpan di tempat strategis seperti didepan pintu Masjid Raya At-Taqwa baik pintu khusus laki-laki maupun perempuan. Kemudian untuk penyimpanan lainnya $Q R$ Code ditempel di kotak infaq, ruang bercermin yang ada di dalam masjid, tempat penitipan barang, kantin, kantor. Otoritas Jasa Keuangan dan kantor Bank Indonesia. Tempat-tempat yang telah disebutkan merupakan tempat ramai yang biasanya banyak orang melewati atau berkunjung. Sehingga diharapkan dengan penempatan QR Code tersebut, banyak jamaah yang tertarik dan berinfaq.

Penerapan fitur $Q R$ Code yang berlaku di At-Taqwa Center tidak memiliki target dalam proses penghimpunan dananya. Sehingga berapapun dana yang diperoleh oleh At-Taqwa Center tidak menjadi suatu masalah bagi kinerja keuangan. Karena sebagian besar keuangan At-Taqwa Center khususnya dalam operasional masjid masih mengandalkan infaq secara non-tunai. Adapun cara berinfaq menggunakan $Q R$ Code At-Taqwa Center adalah sebagai berikut: 1) Jamaah yang ingin berinfaq menggunakan fitur ini harus mengunduh dan menginstal aplikasi penyedia fitur $Q R$ Code yang tersedia di At- Taqwa Centre terlebih dahulu. Kemudian registrasi, login akun, serta mengisi saldo pada aplikasi tersebut. 2) Temukan $Q R$ Code yang tersedia diarea Masjid Raya At-Taqwa atau At-Taqwa Centre untuk melakukan pembayaran. $Q R$ Code tersebut juga dapat difoto dan disimpan dalam galeri karena dapat digunakan kapanpun dan dimanapun. 3) Lalu scan menggunakan kamera pada aplikasi penyedia fitur $Q R$ Code. Infaq pun berhasil dilakukan dengan mudah.

\section{Efektivitas Fitur $Q R$ Code Terhadap Perolehan Dana Infaq}

Tolak ukur efektivitas antara lain: kegunaan, ketepatan dan objektifitas, ruang lingkup, efektivitas biaya, akuntabilitas dan ketepatan waktu.

\section{Kegunaan}

Agar berguna bagi manajemen dalam pelaksanaan fungsi- fungsinya yang lain, suatu rencana harus fleksibel, stabil, berkesinambungan dan sederhana (Handoko, 2015).Fitur $Q R$ Code ini sudah dikatakan fleksibel. Karena dalam penggunaannya, tidak ada batasan minimum nominal dalam berinfaq. Sehingga jamaah dapat berinfaq dengan nominal berapapun melalui fitur ini (Malik, 2020). Selain itu, jamaah juga dapat berinfaq dimana saja tanpa harus ke AtTaqwa Centre asalkan mengetahui $Q R$ Codenya. $Q R$ Code infaq juga tersedia di media sosial milik At-Taqwa Centre. Jika jamaah dalam kondisi terburu-buru dan tidak sempat berinfaq, $Q R$ Code ini dapat difoto menggunakan kamera handphone apapun dan selanjutnya jamaah dapat men-scan $Q R$ Code tersebut dimanapun. $Q R$ Code ini juga dapat di scan oleh berbagai kamera handphone dan mudah terdeteksi walaupun pencahayaan kurang. Sehingga memudahkan jamaah. Namun, itur $Q R$ Code ini tidak cukup stabil dalam hal perolehan dana. Karena dana yang diperoleh mengalami peningkatan dan penurunan setiap bulanny

Meskipun fitur $Q R$ Code digunakan sejak Mei 2018, namun pencatatan dan pembukuannya baru dilaksanakan pada bulan Januari 2019. Pada masa- masa ini fitur $Q R$ Code belum banyak dikenal dan digunakan masyarakat sekitar (Malik, 2020). Kemudian berkesinambungan dan sederhana. Berkesinambungan berarti berkelanjutan. Fitur $Q R$ Code ini terus berjalan dan semakin berkembang sejak awal dimulainya hingga saat ini. Terlebih dunia teknologi semakin maju dan semakin banyak masyarakat yang memiliki smartphone dan mengakses internet. Jika sebelumnya, satu $Q R$ Code hanya untuk aplikasi tertentu. Kini 
ada QRIS yang dikeluarkan oleh Bank Indonesia, yang dalam penggunaannya untuk satu $Q R$ Code untuk beberapa jenis aplikasi yang telah bekerja sama dengan Bank Indonesia. Peralihan sistem dari $Q R$ Code masing- masing hingga memiliki $Q R$ Code yang menjadi standar Indonesia memudahkan At-Taqwa Centre dalam mengelolanya dan memudahkan jamaah bagi penggunaannya.

Sedangkan arti kata sederhana berarti luwes, sahaja, sedang (tidak mewah). Fitur $Q R$ Code ini tidak dibebankan biaya admin sama sekali dan tampilan fisik $Q R$ Code pun sederhana. Berupa kertas yang dapat ditempel dimanapun. Selain itu penggunaan fitur ini sangat mudah dan sederhana bagi masyarakat yang terbiasa menggunakan $e$ wallet dan i-banking. Namun, bagi masyarakat yang masih gaptek, infaq melalui fitur ini perlu memiliki panduan dan promosi lebih. Fitur $Q R$ Code ini sangat berguna bagi manajemen At-Taqwa Centre Kota Cirebon, karena memudahkan jamaah yang tidak membawa uang tunai dan memiliki $e$ wallet/m-banking untuk tetap berinfaq pada Masjid At-Taqwa Cirebon. Laporan keuangannya pun transparan dan ontime ketika ada jamaah yang berinfaq melalui fitur ini. Karena akan ada notifikasi khusus yang masuk ke handphone pengurus At-Taqwa Centre.

\section{Ketepatan dan Objektifitas}

Maksud dari ketepatan dan objektifitas ialah bahwa semua rencana harus dievaluasi untuk mengetahui apakah jelas, ringkas, nyata dan akurat. Dalam hal ini, At-Taqwa center Kota Cirebon melakukan evaluasi setiap bulan untuk rekap perolehan dana serta pengecekan fisik tampilan $Q R$ Code. Untuk tempat yang cukup jauh seperti kantor Otoritas Jasa Keuangan dan Bank Indonesia pengecekan dilakukan tiga bulan sekali dan dana infaq dipantau melalui notifikasi sms dan e-Statements melalui email. Evaluasi yang dilakukan juga untuk melihat apakah fitur $Q R$ Code ini sudah tepat atau belum pelaksanaannya di At-Taqwa Centre.
Melalui laporan keuangan dana, pengurus At-Taqwa Centre juga mengetahui fakta dilapangan mengenai penggunaan fitur QR Code dan dampaknya terhadap perolehan dana. Perolehan dana yang dihimpun dari pemasukan infaq melalui fitur $Q R$ Code mengalami peningkatan dan penurunan yang tidak stabil. Sehingga penggunaan fitur $Q R$ Code sebagai sarana infaq belum tepat dan objektif karena dana yang berhasil dihimpun belum signifikan dibandingkan dengan dana yang dihimpun melalui kotak amal. Jika dilihat, total dana yang berhasil dihimpun tidak cukup untuk memenuhi seluruh kebutuhan operasional Masjid Raya AtTaqwa. Namun jumlahnya masih membantu walaupun rata-rata hanya $0,24 \%$ dari $e$-wallet dan 0,07\% dari Mobile Banking Bank Syariah Mandiri dari total pengeluaran masjid sekitar Rp 245.516.608,- perbulan (Khaerunnisa, 2020).

\section{Ruang Lingkup}

Ruang lingkup yang berkenaan dengan fitur $Q R$ Code adalah sasaran dari penggunaan fitur ini. At-Taqwa Centre memiliki sasaran penggunaan fitur $Q R$ Code yakni jamaah pengguna e-money yang berada disekitar AtTaqwa Centre. Karena banyak dari pengunjung yang menggunakan smartphone dan At-Taqwa Centre memfasilitasi mereka untuk berinfaq secara online agar lebih mudah. Terkait penyimpanan $Q R$ Code yang berada di kantor Otoritas Jasa Keuangan dan Bank Indonesia, itu hanya memperluas lingkup infaq saja bukan sasaran khusus. Kemudian kegiatan yang mendukung sosialisasi $Q R$ Code di At-Taqwa Centre. Sampai saat ini, upaya pengenalan infaq melalui fitur $Q R$ Code kepada masyarakat sekitar atau jamaah masjid adalah melalui media sosial (facebook dan instagram), media banner yang cukup besar dan kode batang yang diletakkan ditempat yang strategis. Namun promosi melalui media sosial pun belum maksimal dilakukan oleh pengurus At-Taqwa Centre karena keterbatasan SDM (Malik, 2020). Pengurus yang bertanggung jawab di bagian 
pengelolaan infaq melalui $Q R$ Code hanya ada satu yakni Ibnu Malik, yang juga memiliki jabatan sebagai Supervisor AtTaqwa Centre.

\section{Efektivitas Biaya}

Fitur $Q R$ Code yang dimiliki At-Taqwa Center disediakan oleh provider dari aplikasi itu sendiri, seperti $Q R$ Code LinkAja disediakan oleh pihak PT.Telkomsel GraPARI, $Q R$ Code DANA disediakan oleh pihak DANA, $Q R$ Code GoPay disediakan oleh GoJek, QR Code OVO disediakan oleh pihak OVO, QR Code Bank Syariah Mandiri disediakan oleh pihak Bank Syariah Mandiri dan terakhir QRIS yang disediakan oleh pihak Bank CIMB Niaga Syariah.. Sehingga At-Taqwa Center hanya sebagai user dan tidak dibebankan biaya sama sekali oleh provider tersebut. Dalam hal ini fitur $Q R$ Code belum dapat dikatakan efektif, karena walaupun biaya yang dikeluarkan tidak ada, namun produktivitas dari hasil penghimpunan dana melalui fitur ini masih belum maksimal dibandingkan dengan infaq secara tunai. Jika $Q R$ Code mengalami kerusakan secara fisik, At-Taqwa Center sudah memiliki stok $Q R$ Code ataupun mencetakulang melalui usaha jasa cetak yang dimiliki At-Taqwa Center secara pribadi.

\section{Akuntabilitas}

Terdapat dua aspek akuntabilitas, yakni tanggung jawab atas pelaksanaan perencanaan dan tanggung jawab atas implementasinya. Untuk tanggung jawab atas pelaksanaan perencanaan, fitur $Q R$ Code ini sudah sesuai rencana. Fitur ini ditempatkan dibeberapa tempat strategis oleh pengurus At-Taqwa Center agar mudah dilihat dan digunakan oleh masyarakat sekitar At- Taqwa Kota Cirebon. Seperti ditempelkan pada kotak infak, dipajang dekat tempat penyimpanan barang, front office, dan wakaf corner.

Kemudian tanggung jawab atas implementasinya adalah sebulan sekali $Q R$ Code ini dicek keberadaan dan tampilan fisiknya. Jika ada kerusakan maka diperbaiki atau diganti dengan $Q R$ Code baru. Setiap bulan juga perolehan dananya dihitung dan dimasukkan kedalam laporan keuangan bulanan. Kemudian hasilnya disalurkan untuk kebutuhan operasional Masjid Raya At-Taqwa. At-Taqwa Center memiliki pengelolaan keuangan yang transparan serta amanah dalam penyaluran dana infaq. Bukti transparan keuangan dapat dilihat dari televisi yang ada diarea masjid ataupun diumumkan melalui microphone masjid setiap minggu setelah shalat jumat. Sehingga jamaah memiliki rasa percaya untuk berinfaq di Masjid Raya At-Taqwa.

\section{Ketepatan Waktu}

Jika suatu perencanaan mengalami perubahan yang terjadi sangat cepat akan dapat menyebabkan rencana tidak tepat atau tidak sesuai untuk berbagai perbedaan waktu. Namun jika perencanaan sudah ditentukan dan pelaksanaannya mencapai waktu yang ditentukan maka rencana tersebut sudah tepat. Dalam hal ini strategi pengimpunan dana infaq melalui fitur $Q R$ Code belum tepat karena At-Taqwa Centre tidak memiliki target terkait perolehan dana yang ingin dicapai. Sehingga dengan tidak adanya target yang ditentukan, At-Taqwa Centre memiliki keterbatasan inovasi dalam melakukan promosi fitur kepada jamaah sasarannya. Akhirnya perolehan dana yang didapat pun tidak signifikan. Berdasarkan laporan keuangan At-Taqwa Centre Kota Cirebon dapat dikatakan bahwa penghimpunan dana infaq melalui fitur QR Code belum efektif, karena dana yang diperoleh tidak stabil setiap bulannya.

Berdasarkan grafik perolehan dana melalui $Q R$ Payment E-Wallet dan $M$ Banking diatas, dapat dilihat bahwa perolehan dana mengalami peningkatan dan penurunan setiap bulannya. Untuk $e$-wallet, hanya pada bulan Mei hingga Juli perolehan dana melalui fitur QR Code mengalami peningkatan secara signifikan sedangkan pada m-banking peningkatan tertinggi pada bulan Mei- Juni. Ini terjadi karena pada bulan Mei bertepatan dengan bulan puasa ramadhan. Pada bulan 
ramadhan, At-Taqwa Centre mengalami peningkatan jamaah dan peningkatan perolehan infaq. Kemudian total dana yang berhasil dihimpun hanya sebesar $\mathrm{Rp}$ 7.874.870,- selama bulan Januari tahun 2019 hingga Januari 2020. Perolehan ini tidak cukup untuk memenuhi seluruh kebutuhan operasional Masjid Raya AtTaqwa yang jika dijumlahkan sebesar Rp 3.003.914.335,- per tahun 2019. Namun perolehan dana melalui fitur $Q R$ Payment $E$ Wallet ini masih membantu walaupun ratarata hanya $0,24 \%$ dan $m$ - banking hanya $0,07 \%$ dari total pengeluaran masjid sekitar Rp 245.516.608,- per bulan (Khaerunnisa, 2020).

\section{SOLUSI DARI FAKTOR PENGHAMBAT DALAM FITUR $Q R$ CODE}

Sebuah sistem yang diterapkan pada sebuah lembaga pasti memiliki faktor pendukung maupun faktor penghambat. Faktor pendukung dalam pelaksanaan penghimpunan dana infaq melalui fitur $Q R$ Code diantaranya:

\section{Dukungan berbagai pihak}

Sebelum strategi ini dilaksanakan, tentu perlu adanya persetujuan dari atasan atau pimpinan lembaga. Dalam hal ini kebijakan dari lembaga adalah mengizinkan diterapkannya fitur $Q R$ Code. Sehingga fitur $Q R$ Code mudah untuk diterapkan di wilayah AtTaqwa Centre. Selain dari dukungan lembaga, fitur $Q R$ Code juga didukung oleh perusahaan penyedia jasa $Q R$ Code dan lembaga keuangan syariah sekitar yang memfasilitasi untuk menerapkan fitur $Q R$ Code. Tahun ini pun At-Taqwa Centre pun didukung penuh oleh Bank Indonesia untuk menggunakan QRIS.

\section{Tidak ada biaya admin}

Dalam penggunaan fitur $Q R$ Code ini bagi jamaah atau masyarakat sekitar At-Taqwa tidak dikenai biaya admin sedikitpun. Bagi At-Taqwa Centre pun tidak ada biaya terkait penyediaan fitur atau admin. Sehingga fitur
$Q R$ Code ini memang di desain seperti kotak amal versi online.

Sedangkan faktor penghambat dalam pelaksanaan penghimpunan dana infaq melalui fitur $Q R$ Code diantaranya:

\section{Tidak ada sentralisasi barcode}

Tidak adanya sentralisasi barcode menyebabkan terlalu banyak akun dalam hal administrasi pembukaan akun. Karena untuk setiap penerapan fitur $Q R$ Code pada satu aplikasi maka harus membuat satu akun. AtTaqwa Center memiliki empat akun untuk empat aplikasi. Sehingga bagi At-Taqwa Center cukup menyulitkan. Namun bulan februari ini, seluruh $Q R$ Code yang dimiliki At-Taqwa Center akan beralih ke QRIS yang dapat digunakan oleh berbagai aplikasi. Sehingga memudahkan At-Taqwa Center dalam proses administrasi akun dan promosi barcode.

\section{Jamaah masih terbiasa infaq secara tunai}

Bagi sebagian jamaah, masih banyak yang belum terbiasa menggunakan $e$-wallet ataupun e-payment. Berbagai pendapat telah penulis dapatkan dari hasil wawancara dengan jamaah Masjid Raya At-Taqwa. Dari hasil wawancara, banyak dari jamaah mengeluhkan penginstalan aplikasi terkait. Beberapa masih belum menggunakan aplikasi $e$-wallet dan menganggap infaq secara tunai lebih mudah.

\section{Sumber Daya Manusia (SDM) yang terbatas}

Faktor penghambat selanjutnya adalah kurangnya pengurus atau sumber daya manusia (SDM) terkait dengan pengelolaan $Q R$ Code. Karena sampai saat ini hanya ada satu orang yang mengerti dan mengelola fitur ini.Kurangnya SDM juga menjadi penyebab kurangnya inovasi dalam hal promosi yang diberikan kepada masyarakat sekitar AtTaqwa. Sehingga promosi terkait penggunaan $Q R$ Code hanya terbatas pada sosial media dan pemasangan banner diarea strategis. Promosi yang dilakukan pun belum maksimal karena tidak dilakukan secara 
rutin. Sejauh ini juga belum ada promosi atau pengenalan khusus kepada jamaah atau masyarakat disekitar At-Taqwa Centre. Dari beberapa wawancara yang peneliti lakukan, banyak yang belum tahu mengenai infaq melalui fitur $Q R$ Code di At-Taqwa Centre. Sehingga wajar bila perolehan dana yang dihimpun belum maksimal karena tidak adanya promosi yang dilakukan secara rutin dan tepat sasaran.

\section{Tidak Memiliki Target Penghimpunan Dana}

Tidak adanya target atas penghimpunan dana yang ingin dicapai membuat pelaksanaan fitur ini belum maksimal. Sehingga yang terjadi adalah At-Taqwa Centre belum memiliki upaya inovasi terbaru terkait promosi fitur ini. At-Taqwa Centre hanya melaksanakan program sesuai rencana tapi belum ada upaya lebih lanjut dalam mengenalkan fitur $Q R$ Code karena bentuk dana disini infaq jariyah secara sukarela dan tidak ada paksaan (Malik, 2020). Dengan berbagai faktor penghambat yang menjadi kendala, At-Taqwa

Centre perlu memikirkan solusi dari permasalahan tersebut supaya penghimpunan dana yang dilakukan mencapai tujuan dan memperoleh dana yang diharapkan. Solusi terkait yang dilakukan oleh At-Taqwa Centre dalam menghadapi permasalahan infaq melalui fitur $Q R$ Code adalah peralihan menggunakan QRIS. QRIS adalah standar $Q R$ Code pembayaran untuk sistem pembayaran Indonesia yang dikembangkan oleh Bank Indonesia dan Asosiasi Sistem Pembayaran Indonesia (ASPI).

Dengan hadirnya QRIS, At-Taqwa Centre hanya perlu memiliki satu $Q R$ Code untuk beberapa aplikasi. Sehingga At-Taqwa Centre tidak mengalami kesulitan dalam hal administrasi. Pengguna pun diuntungkan karena fitur QRIS dapat digunakan pada banyak penyedia aplikasi. Sedangkan untuk penambahan SDM At-Taqwa Centre masih menimbang terkait persoalan biaya yang akan dikeluarkan seperti hasil wawancara yang sebelumnya sudah dijabarkan dalam faktor penghambat $Q R$ Code poin ketiga.

\section{KESIMPULAN}

Berdasarkan hasil penelitian yang telah dilakukan oleh peneliti, dapat disimpulkan bahwa:pertama, Strategi penghimpunan dana yang ada di At-Taqwa Centre Kota Cirebon ada dua yakni secara tunai melalui kotak amal dan secara non-tunai melalui fitur $Q R$ Code. At-Taqwa Centre memulai strategi ini sejak Mei 2018. Namun pelaksanaannya mulai Januari 2019.

Infaq melalui fitur $Q R$ Code dapat melalui aplikasi $e$-wallet dan internet banking. Aplikasi e-wallet yang tersedia adalah OVO, DANA, GOPAY, dan LinkAja. Sedangkan internet banking yang tersedia adalah Bank Syariah Mandiri dan Bank CIMB Niaga Syariah. Cara penggunaan fitur $Q R$ Code cukup mudah yakni menginstal aplikasi penyedia jasa $Q R$ Code terkait, menscan $Q R$ Code milik At-Taqwa Centre dan masukkan nominal infaq yang ingin diberikan. Secara otomatis saldo akan terpotong dan infaq berhasil dilakukan. Kedua,Penghimpunan dana infaq melalui fitur $Q R$ Code pada At-Taqwa Centre belum efektif karena perolehan dana yang dihimpun melalui fitur ini belum signifikan. Juga dilihat dari 6 tolak ukur efektivitas yang ada pada landasan teori yakni kegunaan, ketepatan dan objektifitas, ruang lingkup, efektivitas biaya, akuntabilitas dan ketepatan waktu.

Pada penghimpunan dana infaq melalui fitur $Q R$ Code ini belum sesuai dengan beberapa tolak ukur efektivitas yakni ketepatan dan objektifitas, efektivitas biaya dan juga ketepatan waktu. Ketiga, faktor penghambat dari pelaksanaan infaq melalui fitur $Q R$ Code di At-Taqwa Centre Kota Cirebon diantaranya: Pertama, tidak ada sentralisasi barcode. Kedua, jamaah masih terbiasa infaq secara tunai. Ketiga, Sumber Daya Manusia (SDM) yang terbatas. Dan keempat, tidak memiliki target penghimpunan dana. Solusi yang digunakan oleh At-Taqwa Centre dari faktor penghambat 
tersebut ialah dengan peralihan penggunaan QRIS. Sedangkan untuk penambahan SDM At-Taqwa Centre masih menimbang terkait persoalan biaya yang akan dikeluarkan.

\section{DAFTAR PUSTAKA}

Abidah, A. "Analisis Strategi Fundraising Terhadap Peningkatan Pengelolaan ZIS pada Lembaga Amil Zakat Kabupaten Ponorogo". Kodifikasia, 10:1 (2016).

Abdullah, Jalil, M. M. "Pengurusan Dana Sedekah secara Sistematik: Analisa Peranan Institusi Kerajaan dan Swasta". Jurnal Pengurusan JAWHAR Fakulti Ekonomi dan Muamalat, Universiti Sains Islam Malaysia, 8 (2008).

Agus M, H. W. (2018). "Perancangan Epayment System pada E-wallet Menggunakan Kode QR Berbasis Android". Jurnal Sistem Komputer Universitas Komputer Indonesia, 7: (2018).

Anwar, Y. C. (2018). "Strategi Fundraising dalam Peningkatan Penerimaan Dana Zakat Infaq Shadaqah Di Zakat Center Thoriqotul Jannah Cirebon. Jurnal Manajemen Sekolah Tinggi Ilmu Ekonomi Cirebon, 1:1 (2018).

Arifin, G. Dalil-dalil dan Keutamaan Zakat, Infak, Sedekah Dilengkapi dengan Tinjauan dalam Fiqh 4 Madzhab. Jakarta: PT. Elex Media Komputindo, 2011.

Azwar, S. Metode Penelitian. Yogyakarta: Pustaka Pelajar Offset, 2001.

Bank Indonesia. Peraturan Anggota Dewan Gubernur Nomor 21/18/PADG/2019 tentang Implementasi Standar Nasional Quick Response Code untuk Pembayaran. (2019).

https://www.bi.go.id/id/peraturan/sistempembayaran/Pages/padg_211819.aspx

Bank Indonesia. Edukasi Financial Technology. (2020). https://www.bi.go.id/id/edukasiperlindungan- konsumen/edukasi/produk-dan-jasasp/fintech/Pages/default.aspx

Bank Indonesia. Edukasi Uang Elektronik (2020).

https://www.bi.go.id/id/edukasiperlindungan-

konsumen/edukasi/produk-dan-jasasp/uang-elektronik/Pages/default.aspx

Buhari, H. Strategi Penghimpunan Dana Zakat (2018).

http://digilib.uinsby.ac.id/25850/, 32.

BUMN. Pembayaran Elektronik: Solusi untuk Mempermudah Setiap Transaksi (2020). www.bumn.go.id:

http://www.bumn.go.id/keretaapi/ber ita/0-Pembayaran-Elektronik-SolusiUntuk-Mempermudah-SetiapTransaksi

Chairunnissa, C. Metode Penelitian Ilmiah Aplikasi dalam Pendidikan dan Sosial. Jakarta: Mitra Wacana Media, 2017.

Eka, R. OVO Resmi Dapatkan Lisensi Emoney (Update) (2019).

https://dailysocial.id/post/ovo-lisensi$e$ - money

Fadillah, F. F. (2019, Oktober 17). Kementrian Keuangan Republik Indonesia (2019).

https://www.kemenkeu.go.id/publika si/artikel-dan-opini/sudah-saatnyaberalih-ke-e-money-alat-pembayaranzaman-now/

Fahrurrozi. "Fundraising Berbasis ZIS: Strategi Inkonvensional Mendanai Pendidikan Islam", Ta'dib, XIX:01 (2104).

Fathullah, A. Efektifitas Pendayagunaaan Dana ZIS pada Program Bantuan Pembuatan SIM (Studi Kasus Tukang Ojek dan Supir Angkutan Kota) BAZIS Kota Administrasi Jakarta Barat (2015).

https//.uinjkt.ac.id Fakultas Ilmu Dakwah dan Komunikasi

Fauzia, H.R. "Strategi Penggalangn Dana pada Organisasi Kemanusiaan 
Berbasis Agama", Jurnal Ilmu Kesejahteraan Sosial, 13:1 (2014).

Gojek. Kini Sedekah Bisa di Mana-mana, Cukup Scan CodeQR (2018). https://www.gojek.com/blog/sedekah - langsung-pakai-go-pay/

Handoko, T. H. Manajemen. Yogyakarta: BPFE Yogyakarta, 2015.

Jaja, R. W. (2010). Implementasi Teknologi Barcode dalam Dunia Bisnis (dengan Ms. Visual Basic \& Ms. Access). Yogyakarta: C.V Andi, 2010.

John A. II, R. B. Manajemen Strategis: Formulasi, Implementasi, dan Pengendalian. Jakarta: Salemba Empat, 2013.

Joseph, E. A. "Pemanfaatan Qr-Code Sebagai Media Promosi Toko". Jurnal MNEMONIC, 1:2 (2018).

Katadata. Pengguna Smartphone di Indonesia 2016-2019 (2019). https://databoks.katadata.co.id/datap ublish/2016/08/08/penggunasmartph one-di-indonesia-2016-2019

Katadata. Proyeksi Pengguna Internet di Indonesia $20172023 \quad$ (2019). https://databoks.katadata.co.id/datap ublish/2019/09/09/berapa-penggunainternet-di-indonesia

Malik, I. Implementasi dan Efektivitas fitur QR Code pada At- Taqwa Centre Kota Cirebon (2020) (A. J. Savitri, Interviewer).

Masjid At-Taqwa Cirebon. Laziswa AtTaqwa Kota Cirebon (2019). https://attaqwacirebon.com/laziswaat-taqwa-kota-cirebon/

Masruroh, S. "Efektifitas Penyaluran Zakat, Infak, Sedekah melalui Aplikasi Online", Jurnal Andi Djemma Jurnal Pendidikan, 2:1 (2019).

Muhammad, D. W. (2019). "Pengaruh Persepsi dan Religiusitas Masyarakat terhadap Sikap dan Minat Sedekah Menggunakan Pembayaran Non Tunai”, Jurnal Pendidikan Ilmu Pengetahuan Sosial, 6:1 (2019).
Mukhtar, H. A. Efektivitas Pimpinan (Kepemimpinan Transformatif dan Komitmen Organisasi. Yogyakarta: Deepublish, 2016.

Ni Luh, G. S. "Menakar Keraguan Penggunaan QR Code Dalam Transaksi Bisnis", Jurnal Manajemen dan Bisnis, 16:2 (2016).

Nisa. Perolehan Dana melalui fitur $Q R$ Code pada At-Taqwa Centre (2020) (A. J. Savitri, Interviewer)

Noor, J. Metodologi Penelitian: Skripsi, Tesis, Disertasi, dan Karya Ilmiah. Jakarta: Kencana, 2011.

Philip, H. K. Marketing 4.0. Jakarta: PT. Gramedia Pustaka Utama, 2019.

Pusat Data dan Analisa Tempo. Seri I Perkembangan Fintech di Indonesia. Tempo Publishing (2019).

Rahmi, A. D. (2018). "Telaah Strategi Fundraising Wakaf Tunai Mewujudkan Pemberdayaan Masyarakat". Islamic Economics Quotient Ieq, 1:2 (2018).

Royyan, M. A. "Analisis Strategi Penghimpunan Dana Zakat, Infak, dan Sedekah (Studi Kasus di LAZ Ummat Sejahtera Ponorogo)", Islamic Economics Journal UNIDA Gontor, 3:1 (2017).

Rukajat, A. Pendekatan Penelitian Kualitatif. Yogyakarta: Deepublish, 2018.

Siti, M. U. "Pengaruh Aspek Produktifitas, Fleksibilitas dan Kepuasan SDM terhadap Efektifitas Penghimpunan Dana ZIS di NUCARE LAZIS NU Kabupaten Gresik", QIEMA (Qomaruddin Islamic Economy Magazine), 5:2 (2019).

Setyowati, D. Sedekah via QR Code, Seberapa Menarik bagi Pengguna Uang Elektronik? (2018). https://katadata.co.id/berita/2018/05/ 24/sedekah-via-qr-code-seberapamenarik-bagi-pengguna-uangelektronik

Siregar, SS, H. K. "Analisis Strategi Fundraising Lembaga Amil Zakat 
Melalui Platform E-commerce (Studi Komparatif ACT, Dompet Dhuafa, Rumah Zakat)", al-Mizan, 3:2 (2019).

Shalehuddin, W. S. Risalah Zakat, Infak dan Sedekah. Bandung: Tafakur, 2014.

Sugiyono. Meode Penelitian Kuantitatif, Kualitatif dan $R \& D$. Bandung: Alfabeta, 2016.

Sujarweni, V. W. Metodologi Penelitian Bisnis dan Ekonomi. Yogyakarta: Pustaka Baru, 2015.
Syahbana, F. Transformasi Digital dan Evolusi Aplikasi (2020). https://inet.detik.com/cyberlife/d3913043/transformasi-digital- danevolusi-aplikasi

Uyun, Q. "Zakat, Infaq, Shadaqah dan Wakaf sebagai Konfigurasi Filantropi Islam”, Islamuna, 2:2 (2015).

Yessi, S. A. Strategi Fundraising: Kosnep dan Implementasi. Bandung: Unpad Press, 2016.

Yuda, A. M. "Penerapan QR Code pada Sistem Pemesanan di Industri Retail", Jurnal Matematika, 6:6 (2017). 